\title{
Attributing Another Song to Maroie de Diergnau de Lille
}

\author{
Wendy Pfeffer
}

\begin{abstract}
Maroie de Diergnau is a recognized thirteenth-century woman trouvère to whom one song has been attributed. This article argues that another Old French lyric, Jherusalem grant damage (RS 191, L 265-939), found in the Chansonnier du roi (Paris, Bibliothèque nationale de France, fr. 844, known as trouvere chansonnier $M$ ) should also be attributed to the songstress.
\end{abstract}

Dame Maroie or Maroie de Diergnau was a woman trouvère, identified by Petersen Dyggve $(1973,82,176)$ as from Diergnau, formerly a suburb of Lille with a feudal castle (see also Guesnon 1902, 160). She is named by Andrieu Contredit d'Arras in his song, Bonne, belle et avenant (RS 262, L 7-4), ${ }^{1}$ which ends with these words:

Chancon, va t'en! sans retraire

Vers Dergan soiez errans!

Di Marote, la vaillans,

Qu'elle pent ${ }^{2}$ de joie faire.

(Schmidt 1903, 49)

[Song, go off without delay / toward Diergnau, set out immediately! / Tell the valiant Marote, / that she can rejoice.]

1. In the pages that follow, the following abbreviations are used: RS, to represent Raynaud-Spanke number presented in SPANKE 1955; L, to represent Linker number, presented in Linker 1979; MW, to represent Mölk and Wolfzettel number, presented in Mölk and Wolfzettel 1972; PC to represent PilletCarstens number presented in Pillet and Carstens 1933.

2. Pent is Schmidt's reading; the intended word is peut. 
Andrieu probably died in 1248; scholars assume that Maroie was his contemporary and that she flourished in the first half of the thirteenth century.

In Songs of the Women Trouveres, the editors were happy to attribute to Maroie de Diergnau one lyric, Mout m'abelist quant je voi revenir (RS 1451, L 178-1, MW 964), included in the Paris manuscript Bibliothèque nationale de France fr. 844 (henceforth BnF fr. 844), known as the Chansonnier $d u$ roi (trouvère manuscript $M$, also known as troubadour manuscript $W$ and motet manuscript $R$ ). This attribution comes from the rubricator of the text, who identified Maroie as the author of this song ${ }^{3}$; the text appears in another manuscript, the Chansonnier de Noailles (Bibliothèque nationale de France fr. 12615, trouvère manuscript $T$ f. 169r), whose scribe also gave Maroie credit in the rubric.

The Chansonnier du roi contains another text, Jherusalem, grant damage me fais (RS 191, L 265-939, MW 596), more often labeled anonymous but recently attributed to Jehan de Nuevile by Anna Radaelli (2016). In this article, I suggest that this second lyric, a crusade song, should be attributed to Maroie instead of to Jehan. Here is the text:

Jherusalem, grant damage me fais,

Qui m'as tolu ce que je pluz amoie.

Sachiez de voir ne vos amerai maiz,

Quar c'est la rienz dont j'ai pluz male joie; $\quad 4$

Et bien sovent en souspir et pantais,

Si qu'a bien pou que vers Deu ne m'irais,

Qui m’a osté de grant joie ou j'estoie.

Biauz dous amis, com porroiz endurer

La grant painne por moi en mer salee,

Quant rienz qui soit ne porroit deviser

La grant dolor qui m'est el cuer entree?

Quant me remembre del douz viaire cler

Que je soloie baisier et acoler,

Granz merveille est que je ne sui dervee.

3. See Haines 1998, 105 for a brief discussion of the several rubricators of the Chansonnier du roi. 
Si m'aï Dex, ne puis pas eschaper:

Morir m'estuet, teus est ma destinee;

Si sai de voir que qui muert por amer

Trusques a Deu n'a pas c'une jornee.

Lasse! mieuz vueil en tel jornee entrer

Que je puisse mon douz ami trover,

Que je ne vueill ci remaindre esguaree.

[Jerusalem, you cause me great harm, / taking from me what I loved most. / Know in truth that I will no longer love you, / for that is what brings me the most doleful joy; / often I sigh and am so short of breath / that I am on the verge of turning against God, / who has deprived me of the great joy I had. // Dear sweet beloved, how can you endure / such great pain for my sake on the salty sea, / when nothing in this world could ever express / the great sorrow that has entered my heart? / When I recall the sweet, radiant face / I used to kiss and caress, / it is truly a wonder I do not go mad. // So help me God, I cannot escape: / Die I must, such is my fate; / yet I know truly that whoever dies for love / has more than one day's journey to God. / Alas! I would rather embark on such a journey / to find my dear beloved / than remain here forsaken.] 


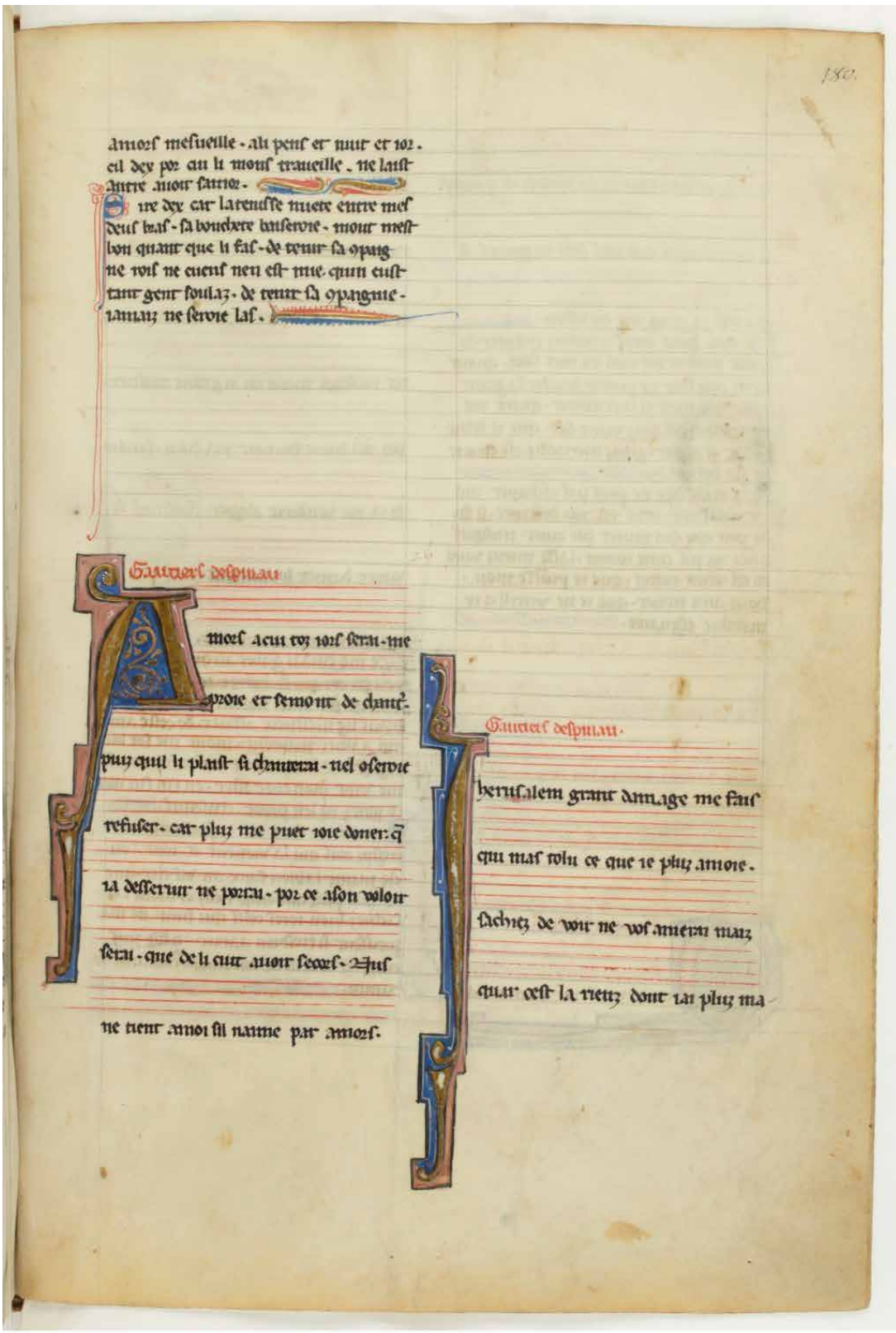

Source gallica.bnf.fr / Bibliothèque nationale de France. Département des Manuscrits. Françals 844

Figure 1. BnF f.fr. 844 f. 180r, source: Gallica, Bibliothèque nationale de France. 


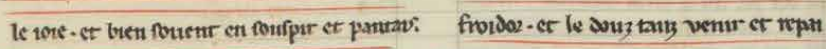

fi qualien pou que verf Jeu ne muat-q

ner- que ti oufe dlanuenr der for lafloz.

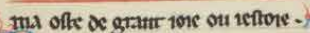

et letbe ver tefpart oy le muner chan

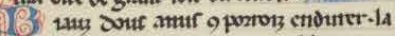
grate pautne por mot en wer falct- quatr thens ctu fort ve porwir deutfer-la graut

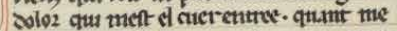
venetubze acl souz mate der. que is polore batfet et acolet-grang inerueille sf que ve

is ful sornce - Da

36 I mate dey ne put par efcbayer - tho

int metuer-teut ent ma actince- at At

oe vor que qui tnuett pos atter. trufquer

a deu na par cute toznce. Laffe metz viel

ctitel toust entrer- quic te purfe mon

Douz anu therer que te ne vuetl a we

mandie egruare.

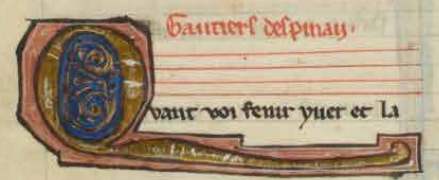

ter meltuet mout en an grate mediet:

Yo2 ma datuc fauc out ma doloz-fation

fia me vondzor aleguer- dufturt $f$

vatse dnet louamett-tuef pou etl

Vor cuit Dorent en torment.

Dite me cuibal gaber au gmenerer- mef

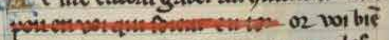
que ne nu une norets: que toz lef matif ne utefhicat affater-de cefte antue ctu aamet mapzent- mout me for bi engaguet- zourencut- atui de moticer? me vint mon cuer ofter - ch fin fint mos it punes, ne lett pzent - chafout. is moor me fout tot le puir amer. St treftoz ceur qui la menent es wour.' ou cle matur labien fatte au vir cler-que te amm plis que nule netiz di mont- st fabrez bien totef eclef qui funt. ne wad pzerfent fitreblent a.mer-" 9 fitt mer

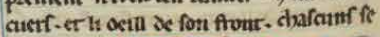

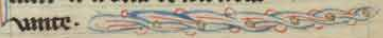

Figure 2. BnF f.fr. 844 f. 180v, source: Gallica, Bibliothèque nationale de France. 
As scholars have long observed, the song appears to be a fragment, composed in coblas doblas with the first or second stanza missing (see, for example, Bédier and Aubry 1909, 275). In the Chansonnier du roi, sufficient space was left after the text to insert another two strophes (see DossQuinby et Al. 2001, 147), with the implication that the scribe recognized the fragmentary nature of this text. Although incomplete in this sole witness, the poem's extant stanzas convey a complete message, the despair of a woman whose love has left, or plans to leave, on crusade. ${ }^{4}$ There can be no doubt as to the female voice.

The creation of the Chansonnier du roi (BnF fr. 844, manuscript M) has been described by John Haines in these terms:

This [. . . d deluxe songbook M-trouv. [was] apparently made for William of Villehardouin, Prince of the Morea (Frankish Greece). This outstanding chansonnier, [. . .] was likely produced in Arras as a wedding gift, perhaps by order of Charles of Anjou, quite possibly for the occasion of William's wedding to his third wife Anna Doukaina of Epiros in late 1258 or early 1259. [. . .] Probably during the chaotic 1260 s or early 1270 s, when the nearly finished chansonnier was likely repossessed by Charles of Anjou, Charles's chancery scribes added some songs to its empty chartae, including a piece praising Charles, Ki de bons est.

(Haines 2013, passim; Haines 2019, 108; 119)

The manuscript's contents show clear elements of accrual. As Gill Page notes, the song book is "an unfinished work, a work in progress, [. . . [ [to which] additional material was added over a lengthy period to form the book as we now have it" $(2014,297)$. John Haines, generally recognized as the expert on the volume, and Page suggest that the chansonnier grew in this fashion:

1) The initial selection of material is made and the process begins to find exemplars.

2) An index is created detailing the works to be included.

3) The copying of text from the gathered exemplars is begun and staves are drawn up for music to be added later.

4. See Galvez 2020, 98-99 and 108 for a recent discussion of the woman's expression of feeling in this song. Galvez notes Radaelli's attribution (274n20); in her discussion of Jherusalem, Galvez finesses the question of authorship. 
4) It is decided to add a new selection of 60 works by the trouvère Thibaut of Navarre, and the whole collection is reordered as a result.

5) The text is copied from exemplars (although in many cases blank spaces are left for verses to be added later).

6) Music from exemplars is added into most but not all of the vacant staves.

(PAGe 2014, 297; Haines, 1998-2002, passim)

It has long been noted that the Index or Table of Contents of $\mathrm{BnF}$ fr. 844, M (which carries its own siglum, Mi [Haines 1998, 48]) does not always provide the same information as the rubrics themselves (see LiNDELÖF and WALlensKöld 1901, 26). As John Haines noted, "most of the MS (25 gatherings) only agrees in part with Mi. Thirty-eight of Mi's 79 poets, or $48 \%$, follow the MS's order [. . .] and just 48 poets, or $60 \%$ have poems identical in number and order to 844" (1998, 48; 1998-2002, 23). Haines himself quoted Brakelmann, noting that the Table of Contents was "une liste des pièces que le scribe se proposait de copier dans les différents recueils qu'il mettait à contribution" [a list of works that the scribe planned to copy from the different collections he had at disposal] (BRAKELMANN 1974, 67). We would be well advised to accept the information in the Table of Contents cautiously.

It is the folios of gathering $\mathrm{xxv}$ that are of most interest to my argument. ${ }^{5}$ First, we observe that Gautier d'Espinal was slated, per the Table of Contents, to appear earlier in the codex. ${ }^{6}$ Here are the texts that were initially proposed for what would become gathering $\mathrm{xxv}$, in the order presented in the Table of Contents (f. Dv), a diplomatic transcription (see also Fig. 3):

5. I follow Haines's understanding of the volume, not that presented by BECK and Веск 1938.

6. Earlier in the Table (f. Dr), Gautier is listed immediately after Guillebers de Bernevile, whose lyrics are largely grouped in folios 131-134; the exceptions are wrongly attributed to Gillebert. These are the titles listed under "Gautiers despinau" on $\mathrm{f}$. Dr:

Comencement de douce s[aison bele] (RS 590, L 77-6), copied on f. 178r;

Aymans fins et verais (RS 199, L 77-2), copied on f. 178v;

Tout efforciez autrui chanter (RS 728, L 77-22), copied on f. 179r;

Outre quiers et ma f[ole pensee] (RS 542, L 77-11), copied on f. 179v;

Desconforte et de ioie parti (RS 1816, L 77-7), copied on f. 181r. 
The plan for gathering $\mathrm{xxv}$ presented on folio Dv

\begin{tabular}{|c|c|c|c|}
\hline author name in red & Incipit & ID & $\begin{array}{l}\text { current location } \\
\text { in MS }\end{array}$ \\
\hline \multirow[t]{15}{*}{ Guios de digon [L 106] } & Quant je voi plus felons rire & RS 1503, L106-9 & $176 r$ \\
\hline & Amors m'ont si enseignie & RS 1088, L 106-2 & $176 v$ \\
\hline & Bien cuidai toute ma vie & RS 1232, L $65-11$ & $173 r$ \\
\hline & Contre le dous tans nouvel & RS 578, L 132-1 & $99 r$ \\
\hline & Uns maus c'ainc mais ne senti & RS 1079, L 106-11 & $173 v$ \\
\hline & Li dous tans nouviaux & RS 1246, L 106-8 & $174 r$ \\
\hline & Chanterai por mon courage & RS 21, L 106-4 & $174 v$ \\
\hline & Amors ma assise rente [sic]* & RS 1088, L 106-2 & $176 v$ \\
\hline & D'amors me doit souvenir & RS 1468, L 184-1 & $168 v$ \\
\hline & De moi dolereus vous chant & RS 317, L 84-10 & $174 v$ \\
\hline & Ma bone fois et loiautez & RS 544, L 155-2 & $183 v$ \\
\hline & Penser ne doit vilanie & RS 1240, L 154-21 & $176 v$ \\
\hline & He, las qu'ai forfait a la & RS 681, L 106-7 & $177 r$ \\
\hline & Quant li dous estez decline & RS 1380, L $68-2$ & $177 r$ \\
\hline & Joie ne guerredons d'amors & RS 2020, L 261-2 & $177 v$ \\
\hline \multirow[t]{18}{*}{ Jehans de Nuevile [L 145] } & Desore mais est raisons & RS 1885 , L $215-2$ & $177 v$ \\
\hline & Quant voi la flor bouton & RS 771, L 106-10 & $178 r$ \\
\hline & Quant je voi par le con[tree] & RS 501, L 77-16 & $178 r$ \\
\hline & Amors a qui tous jors s[erai] & RS 104, L 77-3 & $180 r$ \\
\hline & Jherusalem grant damage & RS 191, L 265-939 & $180 r$ \\
\hline & Quant voi fenir yver & RS 1988, L 77-17 & $180 v$ \\
\hline & En tout le mont ne truis & RS 1816, L 77-8 & $181 r$ \\
\hline & A tous amans** & RS $671=1823$, L 38-10 & $19 v \& 53 r$ \\
\hline & Mout m'abelist & RS 1451, L 178-1 & $181 r$ \\
\hline & La doucor d'este est & RS 588, L 145-2 & $181 v$ \\
\hline & L'an que la froidure faut & RS 393, L 145-3 & $181 v$ \\
\hline & Mout ai estre longement & RS 709, L 145-6 & $182 r$ \\
\hline & Gautrier de formeseles & RS 1822, L 31-1 & $182 r$ \\
\hline & D'amors me plain ne sai a cui & RS $1036=2072 b$, L $145-1$ & $182 v$ \\
\hline & Li dous tans de pascor & RS 2003, L 145-5 & $182 v$ \\
\hline & Quant li boscages retentist & RS 1649, L $145-8$ & $183 r$ \\
\hline & Puis qu'ensi l'as entrepris & RS 1531, L 145-7 & $183 r$ \\
\hline & Guillaumes li viniers amis & RS 1520, L 7-20 & \\
\hline
\end{tabular}

*On $\mathrm{f}$. 176r, the song begins "Mout mont si enseigne", recognized as a variant reading. This and other alternate readings are the topic of a different article.

**These are actually the initial words of the third stanza of the Chastelain de Coucy's Merci clamans de mon fol errement (LEROND 1964, 82-8). 
25) arvir ftu cutacointane.

TO e legiet entrepar

fir mourf ant iemequidie

Dienevengie netore.

G outini oe notbie

(1D) tme et mon war

S. autualef cottes.

1. moof qu fur arinon

CE arvonif trectoiftlos.

(CD) arvir nasfon a

R ogreet sandid

a) Par quel forfart

गो A quar $\alpha^{2}$ Ritini

$\times 170 R^{\circ}$

$+17$
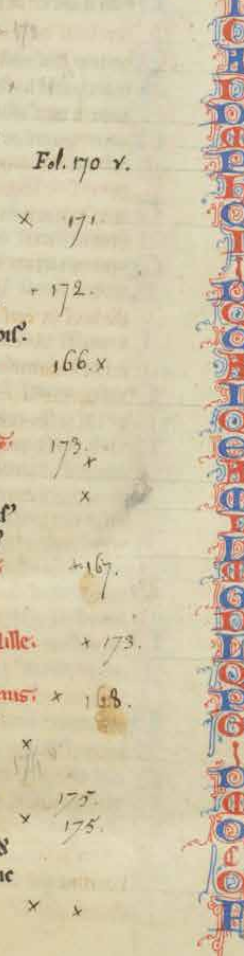
The authors and texts of gathering $x x v$

\begin{tabular}{|c|c|c|c|c|}
\hline folio & scribal attribution & incipit & ID & current attribution \\
\hline \multirow[t]{2}{*}{$177 r$} & Guios de digon & Helas qu'ai forfait a la gent & RS 681, L 106-7 & Guiot de Dijon \\
\hline & Guios de digon & Quant li dous estez deduit & RS 1380, L 68-2 & Garnier d'Arches \\
\hline \multirow[t]{2}{*}{$177 v$} & Guios de digon & Joie ne gueridons d'amors & RS 2020, L 261-2 & le Tresorier de Lille \\
\hline & Guios de digon & Desoremais est raisons & RS 1885, L 215-2 & Raoul de Soissons \\
\hline \multirow[t]{2}{*}{$178 r$} & Guios de digon & Quant voi la flor boutoner & RS 771, L 106-10 & Guiot de Dijon \\
\hline & {$[\text { missing }]^{*}$} & $\begin{array}{l}\text { Comencement de douce } \\
\text { saison bele }\end{array}$ & RS 590, L 77-7 & Gautier d'Espinal \\
\hline \multirow[t]{2}{*}{$178 v$} & Gautiers despinau & Desconforte et de ioie parti & RS 1073, L 77-7 & Gautier d'Espinal \\
\hline & Gautiers despinau & Aymans fins et verais & RS 199, L 77-2 & Gautier d'Espinal \\
\hline $179 r$ & Gautiers despinau & $\begin{array}{l}\text { Touz efforciez aurai chante } \\
\text { souvent }\end{array}$ & RS 728, L 77-22 & Gautier d'Espinal \\
\hline \multirow[t]{2}{*}{$179 v$} & Gautiers despinau & $\begin{array}{l}\text { Outrecuidiers et ma fole } \\
\text { pensee }\end{array}$ & RS 542, L 77-11 & Gautier d'Espinal \\
\hline & Gautiers despinau & Quant je voi par la contree & RS 501, L 77-16 & Gautier d'Espinal \\
\hline \multirow[t]{2}{*}{$180 r$} & Gautiers despinau & Amors a cui toz jors serai & RS 104, L 77-3 & Gautier d'Espinal \\
\hline & Gautier despinau & $\begin{array}{l}\text { Jherusalem grant damage } \\
\text { me fais }\end{array}$ & RS 191, L 265-939 & Anonymous \\
\hline $180 v$ & Gautiers despinau & $\begin{array}{l}\text { Quant voi fenir yver et la } \\
\text { froidor }\end{array}$ & RS 1988, L 77-17 & Gautier d'Espinal \\
\hline \multirow[t]{2}{*}{$181 r$} & Gautiers despinau & $\begin{array}{l}\text { En tot le mont ne truis point } \\
\text { de savoir }\end{array}$ & RS 1816, L 77-8 & Gautier d'Espinal \\
\hline & Maroie de dregnau de lille & $\begin{array}{l}\text { Mout m'abelist quant je vois } \\
\text { revenir }\end{array}$ & RS 1451, L 178-1 & Maroie de Diergnau \\
\hline \multirow[t]{2}{*}{$181 v$} & Jehans de nuevile & La doucor d'este est vele & RS 588, L 145-2 & Jehan de Neuville \\
\hline & Jehan de nuevile & L'an que la froidure faut & RS 393, L 145-3 & Jehan de Neuville \\
\hline \multirow[t]{2}{*}{$182 r$} & Jehans de nuevile & Mout ai este longement & RS709, L 145-6 & Jehan de Neuville \\
\hline & Jehans de nieuvile & Gautrier de formeseles voir & RS 1822, L 31-1 & Cardon \\
\hline \multirow[t]{2}{*}{$182 v$} & Jehans de nuevile & D'amors me plaig ne sai a cui & RS 1036, L 145-1 & Jehan de Neuville \\
\hline & Jehans de nuevile & Li douz tanz de pascor & RS 2003, L 145-5 & Jehan de Neuville \\
\hline \multirow[t]{2}{*}{$183 r$} & Jehans de nuevile & Quant li boschages retentist & RS 1649, L145-8 & Jehan de Neuville \\
\hline & Jehans de nuevile & Quis qu'ensi l'ai entrepris & RS 1531, L 145-7 & Jehan de Neuville \\
\hline \multirow[t]{2}{*}{$183 v$} & Jehans fremaus de lille & De loial amor vueill chanter & RS 832, L 155-1 & Jehan Frumel \\
\hline & Jehans fremaus li courouce & $\begin{array}{l}\text { Ma bone fois et ma loiaus } \\
\text { pensee }\end{array}$ & RS 544, L 155-2 & Jehan Frumel \\
\hline $184 r$ & Jehans fremaus & \multicolumn{2}{|c|}{ Onques ne chantai faintement RS 674, L 155-3 } & Jehan Frumel \\
\hline $184 v$ & Car as aus, & Com amans en desperance & RS 213, L 30-1 & Carasau \\
\hline $185 r$ & Car as aus & $\begin{array}{l}\text { Fine amors m'envoie } \\
\text { [different hand and ink] }\end{array}$ & RS 1716, L 30-2 & Carasau \\
\hline $185 r$ & & $\begin{array}{l}\text { Qui la ve en ditz [Qui la vi } \\
\text { en ditz] }\end{array}$ & PC 10,45 & $\begin{array}{l}\text { Aimeric de Peguil- } \\
\text { han }\end{array}$ \\
\hline
\end{tabular}

*When the illustrated initial was cut from this folio, the authorial attribution was lost. 


\begin{tabular}{|c|c|c|c|c|}
\hline folio & scribal attribution & incipit & ID & current attribution \\
\hline $185 v$ & & $\begin{array}{l}\text { (Qui la ve en ditz, } \\
\text { continued) }\end{array}$ & & \\
\hline $186 r$ & & $\begin{array}{l}\text { Ben volgra s'esser poges [Be } \\
\text { volgra s'esser pogues] }\end{array}$ & PC 244, la & Guiraut d'Espagne \\
\hline $186 v$ & & Sens alegrage [Ses alegratge] & PC 205,5 & $\begin{array}{l}\text { Guilhem Augier } \\
\text { Novella }\end{array}$ \\
\hline $187 r$ & & (Sens alegrage, continued) & & \\
\hline $187 v$ & & $\begin{array}{l}\text { Amors m'art con fuoc am } \\
\text { flama }\end{array}$ & PC 461,20a & Anonymous \\
\hline
\end{tabular}

We can see that in the Table of Contents, Jherusalem is attributed to Jehan de Nuevile (L 145) and that eleven of the eighteen songs attributed to him on this list are now assigned to other poets (an accuracy rate of $38.8 \%)^{?}$

In the volume itself, the order of presentation is somewhat different (see above). The rubrics and incipits on the folios of the gathering, which Haines describes as a quaternion (ff. 177-84) to which a single sheet (f. 185) and a bifolium (ff. 186-7) have been added, for a total of eleven chartae (1998, 75). The appended sheets contain Occitan rather than Old French material, content added later (see Haines 1998, 51 and 75) and included in this chart but not relevant to my subsequent discussion. For the record, folios 180 and 181 form a bifolium within gathering XXV (НАTZIKIRIAKOS and Rachetta 2019, 148).

Of the twenty-nine Old French songs copied, twenty-eight include an attribution (an excision has removed the rubric and opening of Gautier de Dijon's Comencement de douce saison bele); of these twenty-eight, only five are no longer attributed to the trouvère named, a rate of accuracy of $82.1 \%$. The attributions in the chartae of gathering $\mathrm{xxV}$ are demonstrably more trustworthy than those of the Table of Contents, but still leave room for doubt.

Radaelli (2016) described this section of the manuscript in these terms:

[The manuscript] presents the corpus of the nine songs attributed to Gautier d'Espinal (ff. 178v-181r) immediately after the last section devoted to Guios de Digon (ff. 176r-178r); after the insertion into f. 181r

7. In the order of the Table, Raoul de Soissons (L 215), Guiot de Dijon (L 106), Anonymous (L 265), Chastelain de Coucy (L 38), Maroie de Dregnau (L 178), Cardon (L 31), and Andieu Contredit (L 7). 
of the stanza with musical notation Mout m'abelist quant ie voi revenir (RS 1451), attributed to the trouveresse Maroie de Dregnau de Lille and not recorded in the Table, the sequence continues with the transcription of the corpus of the eight songs attributed to Jehan de Nuevile.

(ff. 181v-183v)

As I have shown in detail above, Mout m'abelist is listed in the Table of Contents; it is highly unlikely that the song was added at a later date as the table was an early element of the production process. While additions were made to the manuscript at several points over its history, gathering XXv, planned as including mostly non-Artesian authors (HAINES 1998, 55), is largely in the hand of the original scribe, certainly insofar as Jherusalem and Mout m'abelist are concerned. Unlike the Occitan texts on folios 185r-7v, Jherusalem, on the central bifolium, was not a later addition.

Scholars accept the attribution to Maroie of Mout m'abelist, a song in a woman's voice, attributed to her in both witnesses, the Chansonnier du roi and the Chansonnier de Noailles (see Fig. 4). Jherusalem grant damage me fais is also, clearly, in the woman's voice - there is no doubting the feminine adjectives in its lines 15 and 22. Doss-Quinby et al. included Jherusalem in their anthology $(2001,146-47)$ for this very reason $(2001,6)$; they followed earlier scholars in calling it anonymous. I propose that we attribute Jherusalem to Maroie as well.

One of the general organizing principles of the Chansonnier $d u$ roi is to put works by the same author close together. Following this principle, it would be logical to place a second song by Maroie close to the one clearly attributed to her. I concede that this argument would be stronger if the two songs, Jherusalem and Mout mabelist, were contiguous, rather than separated by two songs attributed to Gautier d'Espinal by the rubricator and by modern scholars. However, the two songs in a woman's voice were copied on the same bifolium, the center section in the initial gathering of four sheets. John Haines remarked that the original compilers of the Chansonnier $d u$ roi paid remarkable attention to the presentation of texts at the middle of the first two gatherings of the book; opening the book in these locations would make these the first elements seen $(1998,83)$. He limited his observations to the first two gatherings, which highlight William of Villehardouin, prince of Morea, the initial intended recipient of the volume, and the Emperor John of Constantinople, in whose realm Morea lay (Haines 1998, 83). Haines described this layout as "an unusual but not isolated phenomenon" $(1998,83)$. I would suggest we extend this observation to gathering $\mathrm{xxv}$, whose original central element forms folios 180 and 


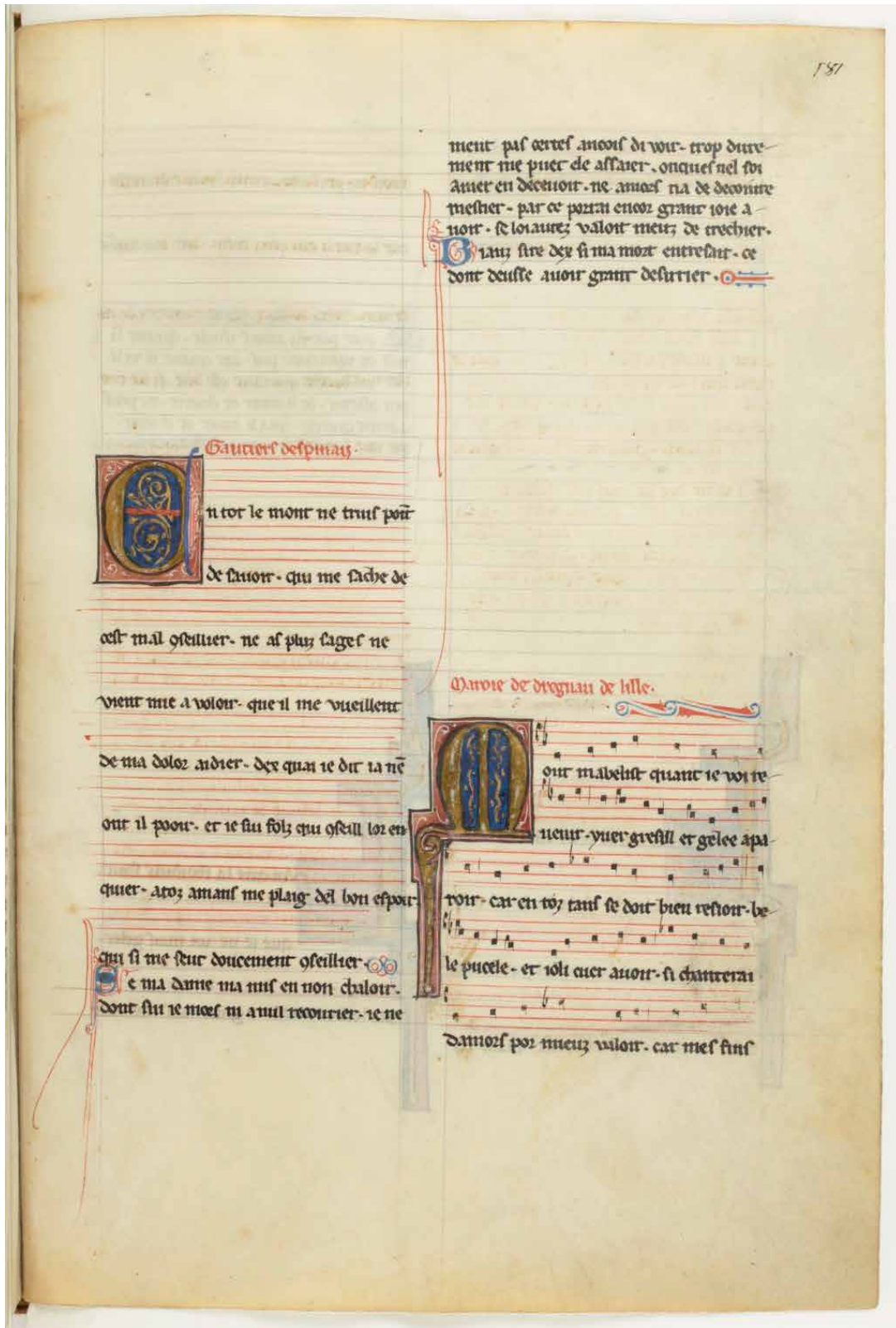

Figure 4. BnF f.fr. 844 f. 181r, source: Gallica, Bibliothèque nationale de France. 
181. It is on this sheet that Maroie de Diergnau's lyrics appear, one song properly rubricated on $\mathrm{f}$. 181r, the other, on $\mathrm{f} .180 r$, misattributed. Again, as Haines noted, "erratic rubrication partly explains the manuscript's characteristic misattributions" (1998, 105-6; 1998-2002, 30).

In their edition of the songs of Gautier d'Espinal, Lindelöf and Wallensköld assigned Jherusalem "probably" to Jehan de Nuevile, based on its presentation in the manuscript $(1901,26)$. The editors considered Gautier d'Espinal's authorship as "very doubtful", "très douteuse" (LindelöF and WAllensKöld 1901, 26), indeed, "more than doubtful", "plus que douteuse" (1901, 60). They suggest that a scribe had inserted Maroie's Mout m'abelist into the set of songs by Jehan de Nuevile and that the copyist of the Chansonnier du roi assigned authorship to Gautier d'Espinal, the trouvère whose works came before these (LINDELÖF and WALLENSKÖLD 1901, 26). In discussing Jherusalem, the two scholars offer an additional argument against crediting Gautier d'Espinal with the song: it is the only Crusade song connected to this trouvère (LiNDELÖF and WALLENSKÖLD 1901, 31). Lindelöf and Wallensköld published Jherusalem in an Appendix to their edition, along with other texts they did not think Gautier had composed (1901, 98).

In his edition of Jehan de Nuevile, Max Richter called attribution of Jherusalem to Jehan as doubtful, Zweifelhafte (1904, 17; 72). He declined even to print the poem, pointing readers to its publication with the works of Gautier d'Espinal. Subsequent editors have declined to assign an author to Jherusalem (see Doss-Quinby et al., 2001, 147 for a list of editions to that date), adding the song to the long list of Old French anonyma. ${ }^{8}$

Anna Radaelli reminds readers that "The song is now generally regarded as anonymous, with recent editors taking this view" (2016). However, she offers this interpretation of the text as presented in the Chansonnier du roi:

If the Table [of Contents] is to be believed, the five texts which conclude Gautier's corpus (including RS 191) should be ascribed to Jehan de Nuevile, adding to the substantial group of eight texts belonging to this trouvère. Since the ordering of the texts may have been influenced by material factors such as a change of source, their displacement with respect to the order in the Table would have occurred at the time of compilation, giving rise to the divergence of attributions (cfr. BATtelLI

8. I have questioned the tendency to assign medieval anonymous works to men, asking pointed questions as to why a medieval male would chose to assume the woman's voice (see Pfeffer 2003, 125). 
1993, 287, n. 17). I am therefore inclined to rescue from anonymity this woman's lament for her departed lover (a «planh d'une femme» for Bédier [and Aubrey] 1909 [277]) and to legitimise its assignment in the Table to the repertory of Jehan de Nuevile, an exponent of the municipal poetic school of Arras of the second half of the XIIIth c., whose collection of songs contains numerous unica preserved by $\mathrm{M}$ from an individual source.

Radaelli based her attribution largely on the Table of Contents, which we have shown cannot be trusted. She discounts the observation of Lindelöf and Wallensköld that Jherusalem incorporates "two epic caesuras in vv. 12 and 13, these being the only examples in the Lorraine trouvère's [i.e. Jehan de Neuville's] corpus" (RAdAelli 2016, citing Lindelöf and WALLENSKÖLD 1901, 39), another reason that Jehan's editors and many others have rejected the attribution of this song in woman's voice to him (Doss-Quinby et al., 2001, 147). Maria Carla Battelli's observations about the Chansonnier du roi (1993), cited by Radaelli (2016), have now been superseded by those of John Haines, whose landmark study of the Chansonnier $d u$ roi formalized the scholarly discipline of musicography (see Haines 1998).

I turn now to versification and poetic style. ${ }^{9}$ Comparing Jherusalem and Mout mabelist, we observe that both songs are composed in stanzas of seven-line decasyllables. They both use fairly restrained rhyme schemes: Mout m'abelist = ababbaa and Jherusalem = ababaab followed by cdcdccd. Jehan de Nuevile much preferred the shorter, heptasyllabic line, used in six of his nine firmly attributed songs. The rhyme scheme of Maroie's songs is simpler than any used by Jehan; in Maroie's individual stanzas we have only two rhymes, whereas Jehan frequently inserted a third rhyme sound if not more in his verse (see Richter 1904, 34-41). Significantly, one of the most interesting structural features of Jherusalem is that it appears to be composed in coblas doblas, a technique that links stanzas in groups of two (consider stanzas two and three). Jehan never used coblas doblas in any of the lyrics firmly attributed to him. Lindelöf and Wallensköld observed that Gautier d'Espinal tended not to "change rhymes" in his lyrics (1901, 29), such that we do not see examples of coblas doblas in his oeuvre either.

9. I would like to thank Daniel E. O'Sullivan for his suggestions on this point. 
For this and other reasons, ${ }^{10}$ these editors attributed Jherusalem to Jehan de Nuevile $(1901,26)$.

Richter noted further that Jehan rarely if ever used alliterative techniques $(1904,40)$, whereas Jherusalem has multiple examples of alliteration and sound repetition for emphasis, from the very first line ('Jherusalem' and 'damage'), where the iteration of $/ \widehat{d} / 3 /$ connects the city with its effect, to the first lines of the last stanza, filled with repeated m's (marked in italics below) that emphasize the speaker, death, and love:

Si m'ait Dex, ne puis pas eschaper:

Morir m'estuet, teus est ma destinee;

Si sai de voir que qui muert por amer

Gautier d'Espinal also used alliteration (consider his Aimanz fins et verais, $\mathrm{R}$ 199 L 77-2), but other arguments eliminate him as an author of Jherusalem.

Doss-Quinby, Grimbert, Pfeffer, and Aubrey made a clear case why Jherusalem should be assigned neither to Gautier nor to Jehan $(2001,147)$. They had no doubt that the author was female but declined to attribute the song to any named woman trouvère. These editors had four criteria which they used to assign female authorship:

(1) a woman is named within the poem as the author [. . .];

(2) a woman is referred to, by name or not, as the interlocutor in a debate poem [. . .];

(3) a woman is named in the rubric or table of contents of a manuscript;

(4) a woman is the speaking subject - the lyric "I" - of the poem (féminité textuelle).

(Doss-Quinby et al., 2001, 6)

Jherusalem, responding only to criterion 4 , was included as an anonymous song in their anthology.

Jherusalem was certainly not composed by Jehan de Nuevile, as Radaelli has recently proposed. Rather than accept this text as anonymous, I suggest we assign it to a recognized woman trouvère, Maroie de Diergnau. The Chansonnier du roi's gathering $\mathrm{xxv}$ includes only one song currently with-

10. Lindelöf and Wallensköld speak of the epic caesura, falling after the fifth beat, in line 12 of Jherusalem as further proof that the song is not by Gautier d'Espinal, though they admit it may simply represent a scribal error $(1901,39)$. 
out a named attribution; there is a logic to assigning this song, clearly in a woman's voice, to the only woman trouvère included in the entire manuscript and whose attributed song appears on the following folio. Maroie was active in thirteenth-century poetic circles; she is recognized as the author of one song by two different manuscript rubricators and by modern scholars. Let us add to her corpus and attribute Jherusalem, grant damage to this talented medieval poet and composer.

\author{
University of Louisville \\ University of Pennsylvania
}

\title{
Works Cited
}

\section{Manuscripts}

Paris, Bibliothèque nationale de France fr. 844 olim 7222

Paris, Bibliothèque nationale de France fr. 12615 olim Suppl. fr. 184

\section{Printed and Digital Sources}

Battelli, Maria Carla. 1993. "Il codice Parigi, Bibl. nat. f. fr. 844: un canzoniere disordinato?" In La filologia romanza e i codici. Atti del Convegno (Messina, Università degli Studi, Facoltà di Lettere e Filosofia, 19-22 dicembre 1991), edited by Saverio Guida and Fortunata Latella. 2 vols. I: 273-308. Messina, Sicania.

- 1996. "Les manuscrits et le texte: typologie des recueils lyriques en ancien français”. Revue des langues romanes 100: 111-29.

—. 1999. "Le antologie poetiche in antico-francese". Critica del Testo 2/1: 141-80.

BECK, Jean and Louise BECK, eds. 1938. Le Manuscrit du Roi, fonds français no 844 de la Bibliothèque nationale. 2 t. Corpus Cantilenarum Medii Aevi, le série, Les chansonniers des troubadours et des trouvères 2. Philadelphia: University of Pennsylvania Press.

Bédier, Joseph and Pierre Aubrey, eds. 1909. Les Chansons de Croisade avec leur mélodies. Paris: Honoré Champion.

Brakelmann, Julius. [1870-1891] 1974. Les Plus Anciens Chansonniers français (XIle siècle). Rpt. Geneva: Slatkine Reprints.

Doss-Quinby, Eglal, Joan Tasker Grimbert, Wendy Pfeffer, and Elizabeth Aubrey, eds. and trans. 2001. Songs of the Women Trouvères. New Haven: Yale University Press.

Galvez, Marisa. 2020. The Subject of Crusade: Lyric, Romance and Materials, 1150 to 1500. Chicago: University of Chicago Press.

Guesnon, A[dolphe]. 1902. "Nouvelles recherches biographiques sur les trouvères artésiens". Le Moyen Age, 2e sér., 6: 137-73. 
Haines, John. 1998. "The Musicography of the "Manuscrit du Roi". Ph.D. dissertation, University of Toronto.

1998-2002. "The Transformations of the 'Manuscrit du Roi". Musica disciplina 52: $5-43$.

- 2013. "Songbook for William of Villehardouin, Prince of Morea (Paris, Bibliothèque nationale de France, fonds français 844): A Crucial Case in the History of Vernacular Song Collections". In Viewing the Morea: Land and People in the Late Medieval Peloponnese, edited by Sharon E. J. Gerstel, 57-109. Washington D.C.: Dumbarton Oaks Research Library and Collection.

- 2019. "Aristocratic Patronage and the Cosmopolitan Vernacular Songbook: The Chansonnier du Roi (M-trouv.) and the French Mediterranean”. In Musical Culture in the World of Adam de la Halle, edited by Jennifer Saltzstein, 95-120. Brill's Companions to the Musical Culture of Medieval and Early Modern Europe 3. Leiden/Boston: Brill.

Hatzikiriakos, Alexandros Maria and Maria Teresa Rachetta. 2019. "Lo Chansonnier du Roi (BnF fr. 844) e la sua storia: un nuovo approccio alle aggiute successive". In Philologie et musicologie: des sources à l'interprétation poético-musicale (XIIe-XVIe siècle), edited by Christelle Chaillou-Amadieu, Oreste Floquet and Marco Grimaldi, 143-58. Musicologie 8. Paris: Classiques Garnier.

Lerond, Alain, ed. 1964. Chansons attribuées au Chastelain de Couci (fin du XIledébut du XIIIe siècle). Publications de la Faculté des lettres et sciences humaines de Rennes 7. Paris: Presses universitaires de France.

Lindelöf, U[no] and A[xel] Wallensköld, eds. 1901. Les Chansons de Gautier d'Épinal, édition critique. Helsingfors: Mémoires de la Société néophilologique à Helsingfors.

Linker, Robert White. 1979. A Bibliography of Old French Lyrics. Romance Monographs 31. University, Mississippi: Romance Monographs, Inc.

Mölк, Ulrich and Friedrich Wolfzettel. 1972. Repertoire métrique de la poésie lyrique française des origines à 1350. Munich: Wilhelm Frank.

PAGE, Gill. 2014. "Literature in Frankish Greece". In A Companion to Latin Greece, 288-325. Brill. ProQuest Ebook http://ebookcentral.proquest.com/lib/upennebooks/detail.action?docID=1877219, consulted 26 December 2020.

Petersen Dyggve, Holger. [1934] 1973. Onomastique des trouvères. Annales Academiae Scientiarum Fennicae B 30, 1. Helsinki Suomalaisen Tiedeakatemian Toimituksia. Rpt. Bibliography and Reference Series 488. Music History and Reference Series 4. New York: Burt Franklin.

Pfeffer, Wendy. 2003. "Complaints of Women, Complaints by Women: Can One Tell Them Apart?" In The Court Reconvenes: Courtly Literature across the Disciplines, Selected Papers from the Ninth Triennial Congress of the International Courtly Literature Society, University of British Columbia 25-31 July 1998, edited by Barbara K. Altmann and Carleton W. Carroll, 125-131. Woodbridge, Suffolk: D. S. Brewer. 
Pillet, Alfred and Henry Carstens. 1933. Bibliographie der Troubadours. Halle: M. Niemeyer.

Radaelli, Anna. 2016. "RS 191, Anonymous (Jehan de Nuevile?)". https://warwick. ac.uk/fac/arts/modernlanguages/research/french/crusades/texts/of/rs191/\#page1.

Richter, Max, ed. 1904. Die Lieder des altfranzösischen Lyrikers Jehan de Nuevile. Inaugural dissertation. Halle a. S.: C. A. Kaemmerer et Co.

Schmidt, Reinhold, ed. 1903. Die Lieder des Andrieu Contredit d'Arras. Inaugural dissertation. Halle a. S.: C. A. Kaemmerer \& Co.

SpAn Ke, Hans, ed. 1980. G. Raynauds Bibliographie des altfranzösischen Liedes neu bearbeitet und ergänzt von Hans Spanke, erster Teil. Leiden: E. J. Brill.

*This research is part of the "Women's Song in Gallo-Romance and German Lyrics" project led by Merixtell Simó, PID2019-108910GB-C21. 